\title{
NOTE
}

\section{Hypoglycemia Associated with the Production of Insulin-like Growth Factor II in a Pancreatic Islet Cell Tumor: A Case Report}

\author{
Jin OOK CHUNG, SE In HONG, DONG HyeOK CHO, JAE HyUK LEE*, DONG Jin CHUNG \\ AND MIN YOUNG CHUNG \\ Department of Internal Medicine, Chonnam National University Medical School, 8 Hak-Dong, Dong-Gu, Gwangju, 501-757, \\ Republic of Korea \\ *Department of Pathology, Chonnam National University Hwasun Hospital, Gwangju, Republic of Korea
}

\begin{abstract}
An insulinoma is characterized by endogenous hyperinsulinemia and hypoglycemia. However, it has been reported that insulinomas with normal levels of plasma insulin and a normal insulin to glucose ratio occur in patients with hypoglycemia. Although overproduction of Insulin-like growth factor II (IGF-II) by non-islet cell tumors such as large mesenchymal tumors, can cause hypoglycemia, no cases of circulating plasma IGF-II from an islet cell tumor contributing to hypoglycemia have been reported. We report here a rare case of a pancreatic islet tumor in a patient with hypoglycemia that was associated with increased plasma IGF-II, which returned to normal after tumor resection.
\end{abstract}

Key words: Hypoglycemia, Insulin-like growth factor II, Insulinoma

(Endocrine Journal 55: 607-612, 2008)

HYPOGLYCEMIA is a common medical condition with many causes. Although hypoglycemia is most common in patients with diabetes mellitus, it also occurs in patients with renal insufficiency, liver disease, congestive heart failure, autoimmune disorders or cancer [1]. An insulinoma, which is the most common type of islet cell tumor, is characterized by endogenous hyperinsulinemia and hypoglycemia [2]. However, insulinomas with normal levels of plasma insulin and a normal insulin to glucose ratio have been reported in hypoglycemic patients [3].

Insulin-like growth factor II is structurally and functionally related to insulin [4], and overproduction of IGF-II by non-islet cell tumors such as large mesenchymal or epithelial tumors, can cause hypoglycemia [5]. In addition, IGF-II also expressed by insulinproducing tumor cells in the pancreas, as well as some endocrine pancreatic tumors that also produce other

Received: December 12, 2007

Accepted: March 20, 2008

Correspondence to: Min Young Chung, M.D., Department of Internal Medicine, Chonnam National University Medical School, 8 Hak-Dong, Dong-Gu, Gwangju, 501-757, Republic of Korea peptides such as glucagons [6]. However, there have been no reports of circulating plasma IGF-II produced by islet cell tumor contributing to hypoglycemia.

Here, we describe a rare case of a pancreatic islet cell tumor in a patient with hypoglycemia that was associated with increased plasma IGF-II levels, which returned to normal after tumor resection.

\section{Case Report}

A 65-year old woman was admitted to our hospital after experiencing recurrent episodes of cold sweats and palpitation for 5 years. These symptoms developed when she was hungry or early in the morning, and then disappeared after eating. The incidence of these symptoms had gradually increased and she experienced general weakness and sweating the day before admission. At the time of admission, she was taking cilnidipine $(10 \mathrm{mg} /$ day $)$ and irbesartan $(150 \mathrm{mg} /$ day $)$ for arterial hypertension, and Hashimoto's thyroiditis had been detected 3 years prior to admission at our facility, but it was well-controlled without pharmacological treatment. She did not smoke or drink and had 
Table 1. The results of a prolonged fast

\begin{tabular}{lccccccccccc}
\hline \multicolumn{1}{c}{ Fasting time $(\mathrm{h})$} & 0 & 6 & 12 & 18 & 24 & 30 & 36 & 42 & 48 & 54 & Range \\
\hline Glucose $(\mathrm{mg} / \mathrm{dl})$ & 106 & 68 & 74 & 109 & 83 & 64 & 70 & 53 & 86 & 45 & $70-110$ \\
Insulin $(\mu \mathrm{U} / \mathrm{ml})$ & 16.3 & $<1.0$ & 4.6 & $<1.0$ & 1.4 & 10.6 & 3.3 & $<1.0$ & $<1.0$ & $<1.0$ & $5-25$ \\
C-peptide $(\mathrm{ng} / \mathrm{ml})$ & 4.0 & 3.6 & 2.1 & 1.7 & 2.2 & 3.0 & 1.6 & 1.1 & 0.9 & 1.6 & $0.3-3.8$ \\
Ratio I/G & 0.15 & $<0.01$ & 0.06 & $<0.01$ & 0.02 & 0.16 & 0.05 & $<0.02$ & $<0.01$ & $<0.02$ & \\
Cortisol $(\mu \mathrm{g} / \mathrm{dl})$ & 18.4 & 7.6 & 1.9 & 2.8 & 8.3 & 7.7 & 5.3 & 6.1 & 7.7 & 12.6 & $3-23$ \\
\hline
\end{tabular}

$\mathrm{H}$, hour, $\mathrm{I} / \mathrm{G}$, insulin to glucose

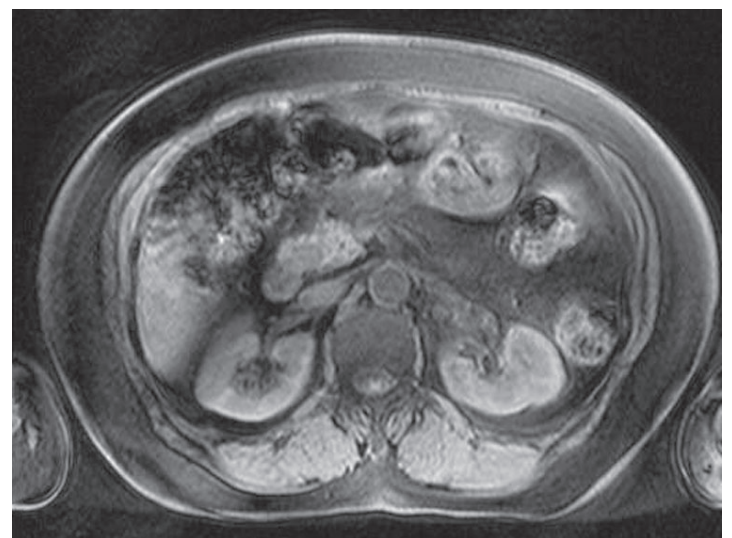

A

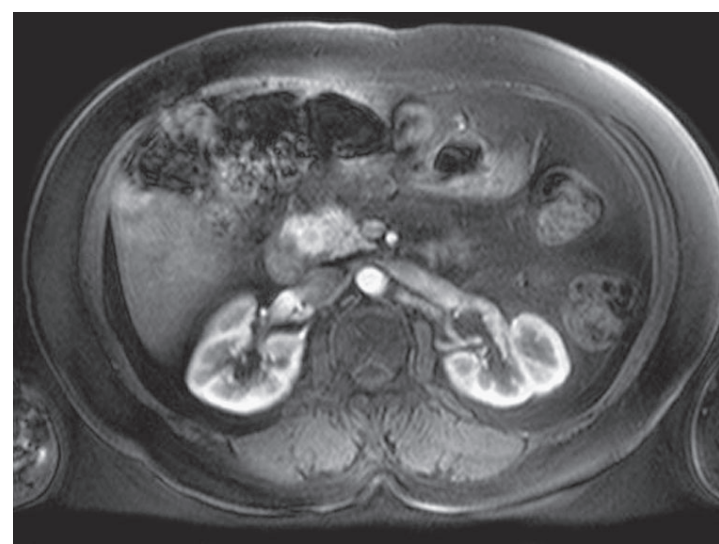

B

Fig. 1. Pancreas MRI showed an approximately $1.5 \mathrm{~cm}$ low signal intensity lesion in the pancreatic head in $\mathrm{T} 1$ (A) and $\mathrm{T} 2$ (not shown). The gadolinium injection revealed peripheral ring enhancement upon arterial enhancement (B). There was no dilatation of the pancreatic duct or significant lymph node enlargement. There were several small cysts in the liver (not shown).

no family history of endocrine disorders or diabetes.

Upon admission, she was $153 \mathrm{~cm}$ tall and weighed $75.5 \mathrm{~kg}$. She gained about 10 kilograms for 5 years. She had a body temperature of $36^{\circ} \mathrm{C}$, a heart rate of 60 beats/min, and a blood pressure of 140/90 $\mathrm{mmHg}$. Physical examination was unremarkable and chest films were normal. Biochemical data were all within the normal limits, and thyroid function studies showed no abnormalities. Anti-thyroglobulin antibodies were positive.

A prolonged fasting test was performed, during which time blood sample were collected every 6 hours to assay the plasma glucose and insulin values. After 54 hours of fasting, she developed sweating and weakness, therefore the test was stopped and venous sampling was performed. Venous sampling indicated that the plasma glucose level was $45 \mathrm{mg} / \mathrm{dL}$ and immunoreactive insulin level was undetectable. In addition, the ratio of plasma insulin $(\mu \mathrm{U} / \mathrm{ml})$ to glucose $(\mathrm{mg} / \mathrm{dl})$ $(\mathrm{I} / \mathrm{G})$ was below 0.02 (cut-off value $<0.3$ ) and the $\mathrm{C}$ peptide level was $1.6 \mathrm{ng} / \mathrm{ml}$ (reference range: $0.3-3.8$ ) (Table 1). Additionally, the glucagon concentration

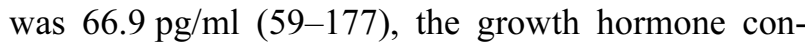
centration was $3.7 \mathrm{ng} / \mathrm{ml}(0-10)$, the epinephrine concentration was $15.7 \mathrm{pg} / \mathrm{ml}(0-110)$, and the concentration of cortisol was $12.6 \mu \mathrm{g} / \mathrm{dl}(3-23)$. Furthermore, the plasma IGF-I level was $274 \mathrm{ng} / \mathrm{ml}$ (71-290), and the IGF-II level was $2889 \mathrm{ng} / \mathrm{ml}$ (467-1038). Anti-insulin antibodies were not detected. Administration of glucose led to immediate relief of her symptoms, therefore Whipple's triad was satisfied. The ACTH level $(0800 \mathrm{~h})$ was $58.2 \mathrm{pg} / \mathrm{ml}(0-60)$, and the cortisol responses to the standard ACTH (cosyntropin $250 \mu \mathrm{g}$ ) stimulation were as follows: basal, $9.3 \mu \mathrm{g} / \mathrm{dl}$; $30 \mathrm{~min}, 20.5 \mu \mathrm{g} / \mathrm{dl}$; $60 \mathrm{~min}, 21.8 \mu \mathrm{g} / \mathrm{dl}$.

Chest Computed tomography (CT) revealed no abnormal findings. However, abdominal CT showed a mass in the head of pancreas that was approximately $1.5 \mathrm{~cm}$, as well as several small simple cysts in the liver. Endoscopic ultrasonography revealed a hypoechoic lesion in the pancreatic head near the uncinate process and no evidence of surrounding lymph node enlargement. Magnetic resonance imaging (MRI) of the pancreas was performed for further evaluation (Fig. 1), 

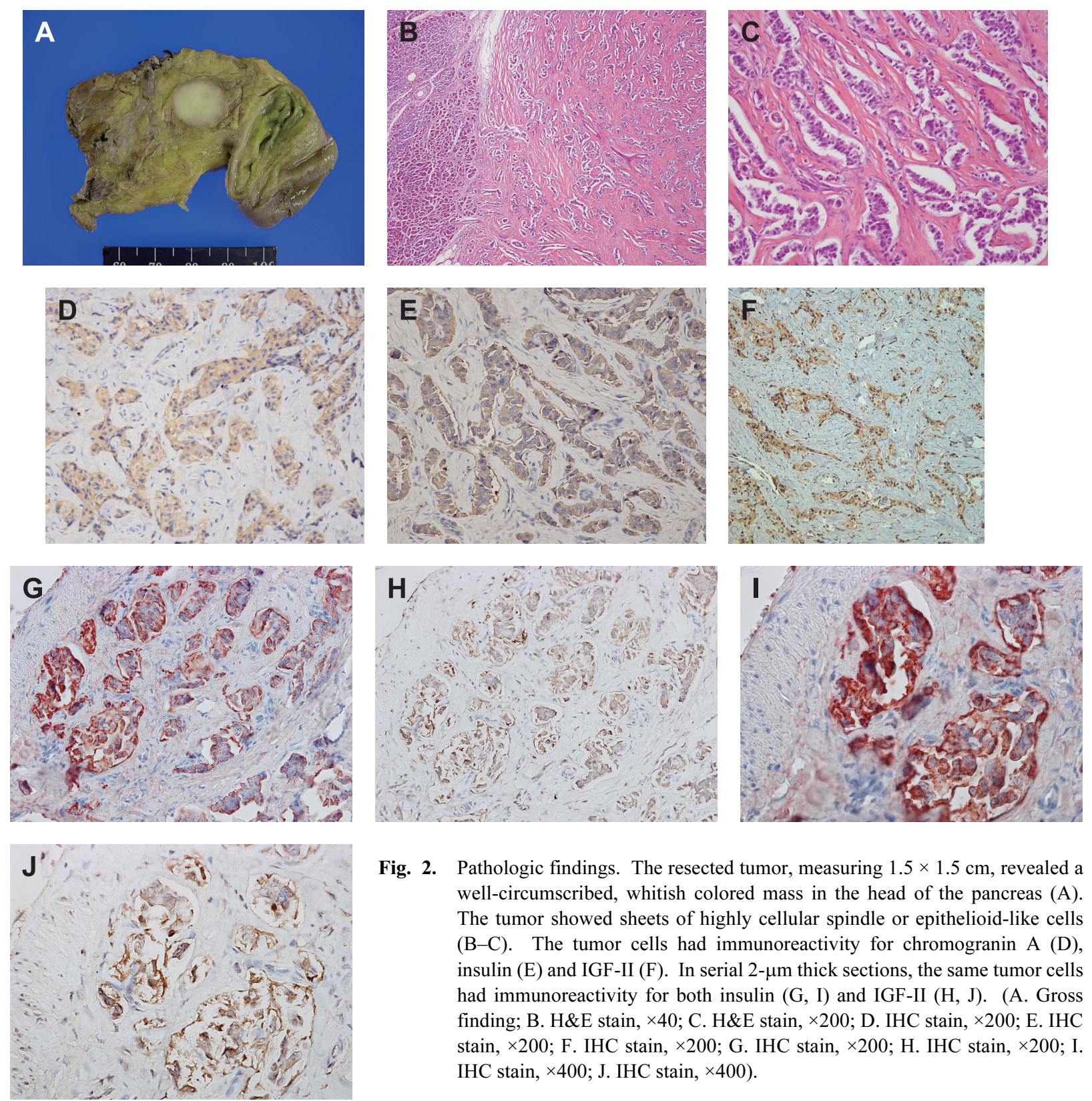

Fig. 2. Pathologic findings. The resected tumor, measuring $1.5 \times 1.5 \mathrm{~cm}$, revealed a well-circumscribed, whitish colored mass in the head of the pancreas (A). The tumor showed sheets of highly cellular spindle or epithelioid-like cells (B-C). The tumor cells had immunoreactivity for chromogranin A (D), insulin (E) and IGF-II (F). In serial 2- $\mu$ m thick sections, the same tumor cells had immunoreactivity for both insulin $(\mathrm{G}, \mathrm{I})$ and IGF-II $(\mathrm{H}, \mathrm{J})$. (A. Gross finding; B. H\&E stain, $\times 40$; C. H\&E stain, $\times 200$; D. IHC stain, $\times 200$; E. IHC stain, $\times 200$; F. IHC stain, $\times 200$; G. IHC stain, $\times 200$; H. IHC stain, $\times 200$; I. IHC stain, $\times 400$; J. IHC stain, $\times 400$ ).

and the patient underwent surgery. During surgery, a $1.5 \times 1.5 \mathrm{~cm}$ sized tumor was found and removed (Fig. 2A). The tumor cells had round and uniform nuclei (Fig. 2B-C), and immunohistochemical (IHC) examination revealed an adenoma originating from the islet cells, which expressed chromogranin A, synaptophysin and insulin (Fig. 2D-E and data now shown). The tumor cells were also IGF-II immunoreactive (Fig. 2F). Because both insulin and IGF-II immunoreactivity were exclusively localized within the cytoplasm of tumor cells, the specimens were cut at $2 \mu \mathrm{m}$, and the serial specimens were examined whether the same tumor cells had immunoreactivity for both insulin and IGF-II. DAB (Diaminobenzidine) and AEC (3-Amino, 9-Ethyl Carbazole) chromogens were applied to develop the IGF-II and insulin stain, respectively. The insulin and IGF-II immunostaining showed a cytoplasmatic distribution pattern in same tumor cells, which suggested that the same tumor cells might secrete both peptides (Fig. 2G-J).

Postoperatively, the plasma IGF-II level fell to $680.81 \mathrm{ng} / \mathrm{ml}$ (reference range: 467-1038), and the 
fasting plasma glucose and insulin level were $93 \mathrm{mg} / \mathrm{dl}$ and $10.6 \mu \mathrm{U} / \mathrm{ml}$ respectively. The patient had a complete recovery from the previous symptoms and remained normally glucose tolerant.

\section{Discussion}

Although insulinoma derived from pancreatic $\beta$ cells is a rare disorder [7], it is the most common cause of hypoglycemia due to endogenous hyperinsulinemia [2]. When evaluating patients with symptoms of hypoglycemia, a 72-hour fast, which evaluates the integrity of the patient's endogenous suppression of $\beta$ cell polypeptides in the presence of hypoglycemia, is the standard diagnostic test [8]. Hypoglycemia in patients with insulinoma is characterized by low plasma glucose with an inappropriate level of plasma insulin [9]. Therefore a diagnosis of insulinoma is based on Whipple's triad in addition to the non-suppressed levels of insulin and C-peptide [10]. Service et al. [11] reported that a concentration of plasma insulin greater than $6 \mu \mathrm{U} / \mathrm{mL}$ in the presence of hypoglycemia is indicative of insulin-mediated hypoglycemia, and a ratio of plasma insulin $(\mu \mathrm{U} / \mathrm{mL})$ to glucose $(\mathrm{mg} / \mathrm{dL})$ greater than 0.3 is indicative of insulinoma [12]. When plasma glucose levels fall into the hypoglycemic range during fasting, the levels of plasma insulin may fluctuate in patient with insulinoma. However, because clearance of C-peptides from the plasma is slower than that of insulin, C-peptides are less likely to show marked changes in plasma concentrations and should be a valuable adjunct in ascertaining the status of insulin secretion in patients suspected to have insulinoma [13]. During hypoglycemia, patients with insulinoma may exhibit deficient counterregulatory hormone responses, which are reversed after surgical cure [14]. These abnormalities in patients with insulinoma may be associated with hyperinsulinemia per se or recurrent episodes of hypoglycemia [14]. In this case, there were impaired counterregulatory hormone responses during hypoglycemia before surgery, but we did not confirm if there was the reversal of these defective hormone responses after tumor resection. However, the patient did not experience the recurrent episodes of the hypoglycemic symptoms during fasting after surgery.

Although hyperinsulinemia is requisite for the diagnosis of hypoglycemia, insulinomas in patients with- out abnormal plasma insulin levels and $\mathrm{I} / \mathrm{G}$ ratios have been reported $[3,13]$. However, the mechanism by which this occurs is unclear, although there are several possible considerations for this phenomenon. Insulinoma secretes insulin in short bursts, which causes wide fluctuations in the plasma insulin levels [13], however, it is unlikely that this occurred in the present case because the plasma C-peptide level was elevated during the hypoglycemic episode. Another possible explanation is that the insulinoma may secrete abnormal insulin which is easily broken down [13]. Although insulin is excessively secreted, most of it may be metabolized in the liver, resulting in normal peripheral insulin levels, which would explain the occurrence of frequent hypoglycemia with normal insulin levels. Also, insulinoma may release excessive amounts of proinsulin, and although circulating proinsulin has substantially less biologic potency than the corresponding insulin molecules, its failure to be suppressed by decreasing glucose concentrations during fasting may result in hypoglycemia [5, 15]. Finally, circulating IGF-II may contribute to hypoglycemia in subjects with insulinoma.

The insulin-like growth factor (IGF) system consists of the IGF ligands (IGF-I and IGF-II), IGF receptors (IGF-I receptor, IGF-II receptor, and insulin receptor) and six IGF-binding proteins [16]. IGF-II is structurally and functionally related to insulin [4], and can exert an insulin-like activity by binding to the insulin receptor and the IGF-I receptor [17]. In addition, it has been reported that IGF-II is a cause of hypoglycemia by non-islet cell tumors [5]. The circulating levels of total IGF-II in patients with tumor-induced hypoglycemia varies from even normal to modestly elevated in the literature $[5,18-20]$. Overproduction of an incompletely processed form of IGF-II with a higher molecular weight is found in patients with non- $\beta$ cell tumors and hypoglycemia, and the free serum IGF-II and pro-IGF-II levels are often elevated [21]. However, the IGF-II levels return to normal after surgical resection of the tumor, which leads to the resolution of hypoglycemia [22].

Pipeleers et al. [23], conducted an in vitro study that found that human insulin-producing tissue synthesized and released an insulin-like material of high molecular weight, as well as insulin and pro-insulin. In addition, IGF-II immuno-reactivity has been localized to the insulin-producing beta cells in the islets of Langerhans [24]. Recently, Hoog A et al. [6] reported that, based 
on immunohistochemical, biochemical and in situ hybridization findings, IGF-II was expressed in insulinproducing tumors. However, Merimee found serum IGF-II concentrations to be within the normal range in patients with insulinoma and hypoglycemia [25].

In this case, the insulin levels fluctuated with prolongation of the fast; however the plasma C-peptide levels showed no marked variation and were not suppressed. In addition, when hypoglycemic symptoms developed plasma insulin was undetectable, and the plasma IGF-II level was elevated. Additionally, the tumor cells were immunoreactive for insulin and IGFII. However, after the tumor was removed, the plasma IGF-II level fell to normal, and the hypoglycemia disappeared. Taken together, these results indicate that the tumor in this case was an autonomous insulin- producing tumor that also caused non-insulin mediated hypoglycemia, although we measured total IGF-II and did not distinguish incompletely processed IGF-II from the normal one. The low level of insulin at the time of hypoglycemia excluded surreptitious injection of insulin, and the patient's clinical history was not suggestive of sulfonylurea abuse although the sulfonylurea levels were not measured.

These results of this case suggest that increased plasma IGF-II may be at least partially responsible for the induction of hypoglycemia in patients with insulinoma that reveals an undetectable plasma insulin level; however, additional investigations to evaluate the precise effects of IGF-II produced by islet cell tumors on glucose metabolism are warranted.

\section{References}

1. Shilo S, Berezovsky S, Friedlander Y, Sonnenblick M (1998) Hypoglycemia in hospitalized nondiabetic older patients. J Am Geriatr Soc 46: 978-982.

2. Marks V, Teale JD (1996) Investigation of hypoglycaemia. Clin Endocrinol (Oxf) 44: 133-136.

3. Hattori N, Ishihara T, Saiki Y, Moridera K, Hino M, Ikekubo K, Kurahachi H (1994) Insulinoma with normal plasma insulin concentrations and insulin/glucose ratios during hypoglycemic episodes. Intern Med 33: 813-816.

4. Rinderknecht E, Humbel RE. Primary structure of human insulin-like growth factor II (1978) FEBS Lett 89: 283-286.

5. Le Roith D (1999) Tumor-induced hypoglycemia. $N$ Engl J Med 341: 757-758.

6. Hoog A, Kjellman M, Nordqvist AC, Hoog CM, Juhlin C, Falkmer S, Schalling M, Grimelius L (2001) Insulin-like growth factor II in endocrine pancreatic tumours. Immunohistochemical, biochemical and in situ hybridization findings. APMIS 109: 127-140.

7. Service FJ, McMahon MM, O'Brien PC, Ballard DJ (1991) Functioning insulinoma--incidence, recurrence, and long-term survival of patients: a 60-year study. Mayo Clin Proc 66: 711-719.

8. Service FJ (1995) Hypoglycemic disorders. $N$ Engl J Med 332: 1144-1152.

9. Marks V (1971) Progress report. Diagnosis of insulinoma. Gut 12: 835-843.

10. Virally ML, Guillausseau PJ (1999) Hypoglycemia in adults. Diabetes Metab 25: 477-490.

11. Service FJ, Dale AJ, Elveback LR, Jiang NS (1976) Insulinoma: clinical and diagnostic features of 60 con- secutive cases. Mayo Clin Proc 51: 417-429.

12. Finlayson E, Clark OH (2004) Surgical treatment of insulinomas. Surg Clin North Am 84: 775-785.

13. Fajans SS, Vinik AI (1989) Insulin-producing islet cell tumors. Endocrinol Metab Clin North Am 18: 45-74.

14. Davis MR, Shamoon H (1991) Deficient counterregulatory hormone responses during hypoglycemia in a patient with insulinoma. J Clin Endocrinol Metab 72: 788-792.

15. Gruppuso PA, Gorden P, Kahn CR, Cornblath M, Zeller WP, Schwartz R (1984) Familial hyperproinsulinemia due to a proposed defect in conversion of proinsulin to insulin. $N$ Engl J Med 311: 629-634.

16. Furstenberger G, Senn HJ (2002) Insulin-like growth factors and cancer. Lancet Oncol 3: 298-302.

17. Phillips LS, Robertson DG (1993) Insulin-like growth factors and non-islet cell tumor hypoglycemia. Metabolism 42: 1093-1101.

18. Eguchi T, Tokuyama A, Tanaka Y, Takahashi Y, Kawahara G, Aiba M, Inishi Y, Minowa H (2001) Hypoglycemia associated with the production of insulin-like growth factor II in adrenocortical carcinoma. Intern Med 40: 759-763.

19. Shapiro ET, Bell GI, Polonsky KS, Rubenstein AH, Kew MC, Tager HS (1990) Tumor hypoglycemia: relationship to high molecular weight insulin-like growth factor-II. J Clin Invest 85: 1672-1679.

20. Zapf J, Futo E, Peter M, Froesch ER (1992) Can "big" insulin-like growth factor II in serum of tumor patients account for the development of extrapancreatic tumor hypoglycemia? J Clin Invest 90: 2574-2584.

21. Frystyk J, Skjaerbaek C, Zapf J, Orskov H (1998) 
Increased levels of circulating free insulin-like growth factors in patients with non-islet cell tumour hypoglycaemia. Diabetologia 41: 589-594.

22. Ron D, Powers AC, Pandian MR, Godine JE, Axelrod L (1989) Increased insulin-like growth factor II production and consequent suppression of growth hormone secretion: a dual mechanism for tumor-induced hypoglycemia. J Clin Endocrinol Metab 68: 701-706.

23. Pipeleers DG, Levy J, Malaisse-Lagae F, Malaisse WJ (1975) In vitro biosynthesis and release of three im- muno-reactive insulin-like components by a human insulinoma. Diabete Metab 1: 7-11.

24. Hoog A, Grimelius L, Falkmer S, Sara VR (1993) A high-molecular IGF-2 immunoreactive peptide (proIGF-2?) in the insulin cells of the islets of Langerhans in pancreas of man and rat. Regul Pept 47: 275-283.

25. Merimee TJ (1986) Insulin-like growth factors in patients with nonislet cell tumors and hypoglycemia. Metabolism 35: 360-363. 